of the Royal Air Force during the second world war. A plea is made for increased care in the selection of persons to be fitted .with contact lenses.

This investigation was carried out with a grant from the Medical Research Council.

I wish to express my thanks to Sir Stewart Duke-Elder and Mr. F. A. Williamson-Noble for their help and advice, and to Air Marshal P. C. Livingston for permission to peruse the war-time records of the Royal Air Force.

I am greatly indebted to Messrs. Clement Clarke, Ltd., Messrs. Theodore Hamblin, Ltd., Messrs. Davis Keeler, Ltd., and Mr. Keith Clifford Hall for their co-operation, and to all ophthalmic surgeons who allowed me to write to their patients.

\title{
REPERENCES
}

BRUCE (1937).-Amer. J. Ophthal., 20, 605.

Cross, A. G. (1947).-Ophthal. Lit., 1, 107.

DaLlos. J. (1936).-Arch. of Ophthal., 15, 617.

DICKINSON, F. and CLIFFORD HALL, K. G. (1946).-An Introduction to the Prescribing and Fitting of Contact Lenses. Hammond and Co. London. GYORFFY, I. vON. (1940).-Klin.-Monatsbl. f. Augenheilk., 104, 81.

GYORFFY, S. VON (1944).-Ophthalmologica, 108, 44.

MANN, I. (1938).-Trans. Ophthal. Soc. U.K., 58 (i), 109. (1944).-Brit.J. Ophthal., 28, 441.

Obrig, T. E. (1947). - Contact Lenses Chilton Co. Phila.

RIDLEY, F. (1946).-Proc. Roy. Soc. Med., 39, 842.

Treissman, H. and Plaice, E. A. (1946).-Principles of the Contact Lens. Henry Kimpton, London.

Will.iAMs, DARCy J. (1945). - Trans. Ophthal. Soc. Austral., 5, 72.

Williamson-NobLe, F. A. (1938).-Trans. Ophthal. Soc. U.K., 58 (ii), 535.

\section{THE NATURE OF THE MALIGNANT CHOROIDAL MELANOMATA*}

BY

\section{EUGENE WOLFF}

LONDON

Writing in 1904, Parsons upheld Ribbert's (1911) view that malignant pigmented choroidal growths were sarcomata, and is still of the same opinion. Dawson (1925) re-affirmed Unna's (1893) suggestion that these growths were epithelial in origin and therefore carcinomata, but the great majority of authors now hold the neurogenic theory, and believe that choroidal melanomata are derived from the cells of Schwann belonging to the ciliary nerves.

I would like at the outset to return to certain well-known basic

Dedicated to Professor J. Meller.

- Received for publication, March 9; 1949. 
facts which latterly have not received the attention obviously due to them.

The cells of a sarcoma differ from those of a carcinoma in that they do not excite any local tissue reaction, whereas usually a carcinoma produces a well-marked stroma reaction, so that groups of epithelial cells become surrounded by fibrous tissue and hence assume an alveolar arrangement. That the choroid can produce such a reaction is shown by the fibrous tissue formed round secondary nodules from a scirrhus of the breast. The cells of a malignant 'melanoma behave like a sarcoma in that they produce no tissue reaction. In the (so-called) alveolar type of choroidal melanoma the boundaries of the alveoli are formed by blood-vessels or pigment, never by new-formed fibrous tissue.

The blood-vessels of a sarcoma are usually abundant, and present the characters of blood-vessels in the process of development, consisting of channels surrounded by a delicate endothelium, or possibly by actual tumour cells. In a carcinoma, on the other hand, the small blood-vessels, although they may be numerous, are confined to the tissues intervening between the cell-masses, and do not extend into the latter; they present the appearance of ordinary arterioles, venules and capillaries (Lawrence and Johnson, 1915). It will be seen that the blood-vessels of the malignant melanoma are identical with those of a sarcoma.

The cells of a sarcoma do not lie in actual apposition, but are separated from each other by varying amounts of ground substance. It is true that in a malignant melanoma of the choroid the cells are usually so closely packed that no intercellular ground substance is seen ; but this may be present in varying amount, and can apparently always be demonstrated in teased preparations after fixation with chromic acid. Like a sarcoma, too, the spread of a malignant melanoma of the choroid is by blood-vessels, and only very rarely by lymphatics.

Ribbert (1911) showed that malignant melanomata could arise from branched chromatophores, and it has since been confirmed a great many times that a teased preparation of what on microscopic section appears to be a spindle-celled tumour. of the choroid is in fact composed of chromatophores in all stages of development. The important fact brought out by Ribbert's work was that in secondary nodules found in the brain and liver there were cells identical with choroidal chromatophores. As further evidence of this I would emphasize that all the following types of pigmented and nonpigmented cells may be found in one and the same tumour: chromatophores with four, three, two, one or no processes. The last of these appear as large pigmented round cells (Figs. 1 and $2)$, and these pigmented round cells packed close together become 


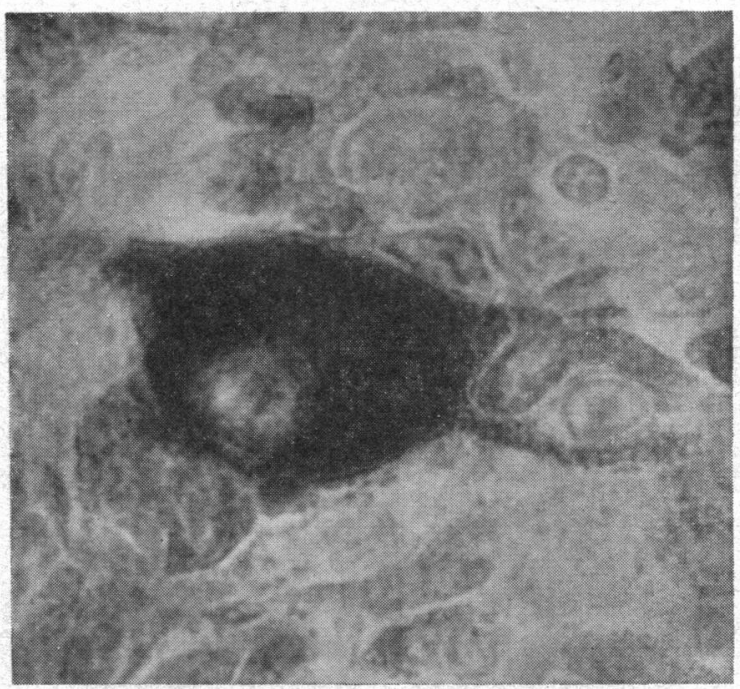

FIG. 1.

Typical chromatophore. The small round granules and the nucleus are visible.

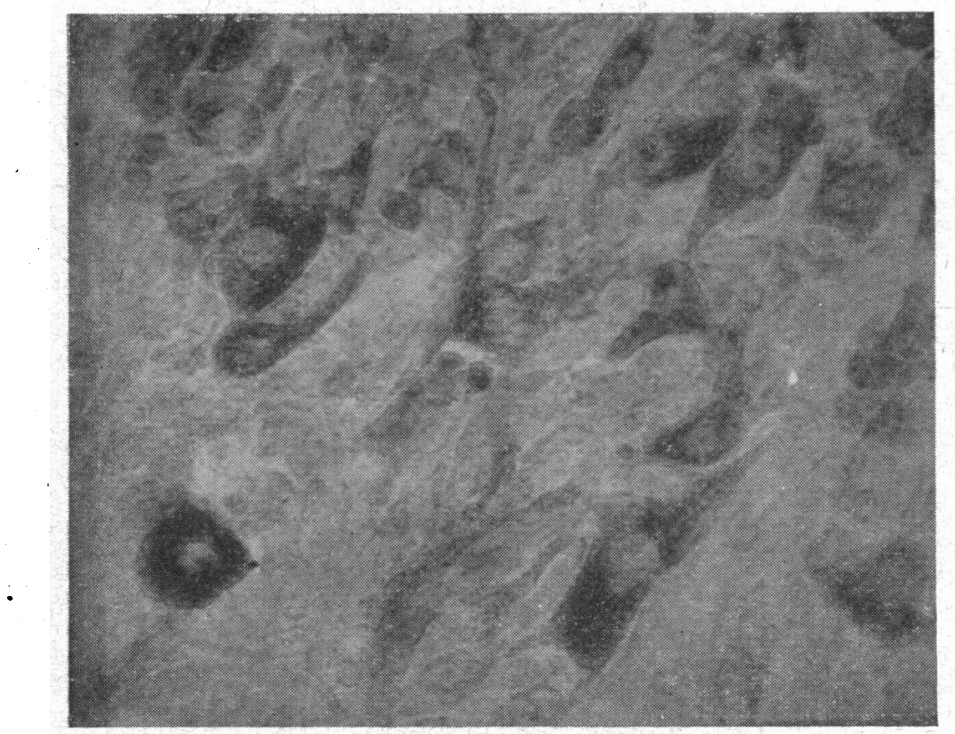

FIG. 2.

Chromatophores with 4, 3, 2, 1 and no processes are seen. 


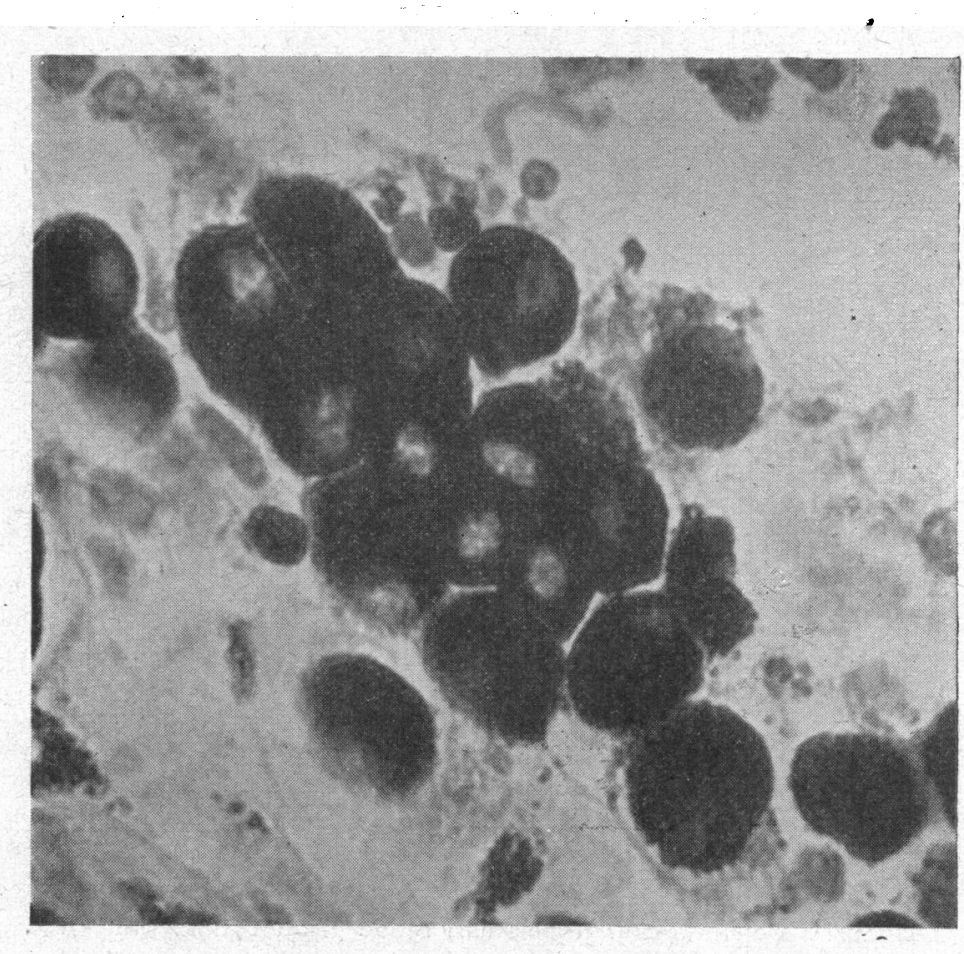

FIG. 3.

Large round and polyhedral chromatophores.

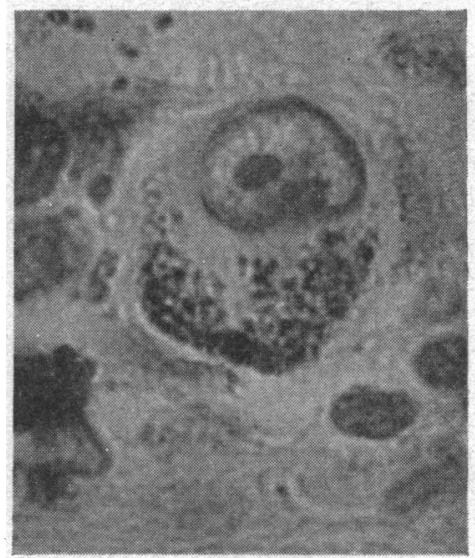

옹 
polyhedral (Fig. 3). Finally there are pigmented spindle cells and pigmented small round cells. The nucleus is usually visible and is large, pale-staining, vesicular, with one or more well marked nucleoli. The following non-pigmented cells are found : large round cells like the pigmented ones but without pigmentthese non-pigmented round cells when closely packed become polyhedral cells with large vesicular nuclei and abundant protoplasm (epithelioid cells) (Fig. 4), and finally typical spindle (Fig. 5) and round cells.

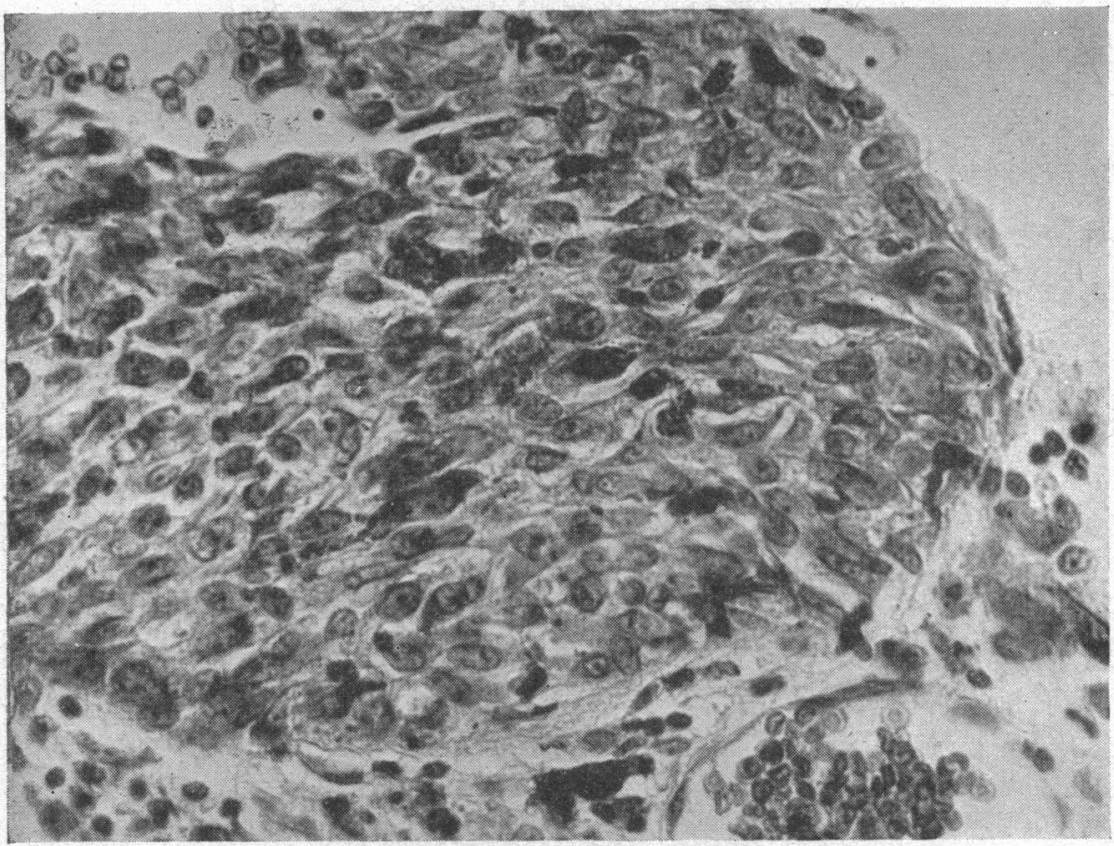

Fic. 5.

Portion of growth with typical spindle cells.

It will be noted that the general characteristics of the nuclei of all these cells are the same. Also the pigment in nearly all the pigmented tumour cells consists of small round granules of the same size, like those of the normal chromatophore. I would also stress the fact that there are intermediate forms of all the above-named cells, so that it might be quite impossible to say whether a given cell is spindle-shaped -or epithelioid (Fig. 6). Thus a careful examination of a tumour containing all the above-named cells leaves little doubt that the chromatophore is the essential cell. 
The fact that some malignant choroidal melanomata consist largely of epithelioid cells has been brought forward as evidence that the growth is or may be a carcinoma. The above explanation of the epithelioid appearance of the cells will, I think, rule out this suggestion.

The relation of the non-pigmented to the pigmented ones is, I suggest, that of the subconjunctival chromatophores in the fair and

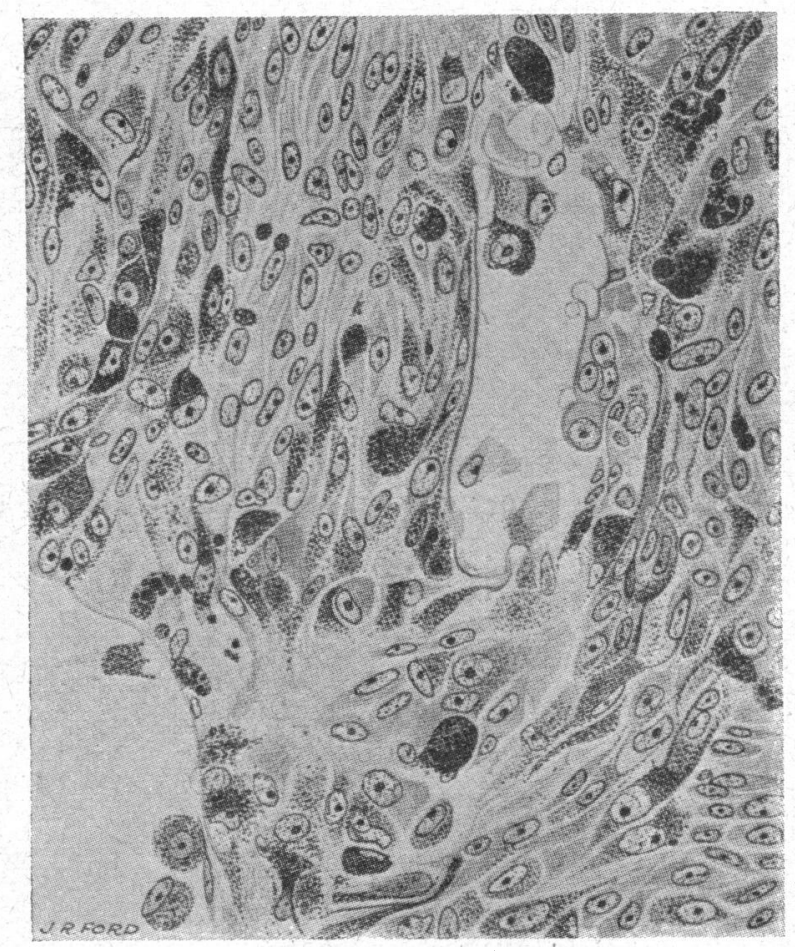

FIG. 6.

Malignant Melanoma of Choroid. Epithelioid and spindle-cells in same tumour, with intermediate forms.

dark races of mankind. In the former they are usually nonpigmented, but the pigment can be demonstrated by the Dopa reaction or silver stains. There is thus no essential difference.

Finally Dawson's view that the pigment of the choroidal chromatophores comes from the retinal pigment epithelium cannot be upheld. (Collins, 1926; Mann, 1926; Wolff, 1948.) It will thus be seen, and this is a very important fact, that if there were no question of pigment the so-called spindle-celled choroidal growth 
would in any other part of the body undoubtedly be diagnosed as a sarcoma and not a carcinoma.

Now we come to the claims of the neurogenic theory. The main reason why this has been brought forward is that it brings the choroidal growths into line with Masson's (1926) view with regard to melanomata of the skin. But there are serious objections to Masson's theory. In the first place definite epithelial downgrowths are well known to occur in simple naevi, and it has been shown repeatedly that these may develop into malignant pigmented growths. More fundamental still is the fact that the morphology, embryology and results of section of their nerve-supply appear to show that the tactile cells of the Merkel-Ranvier and Meissner's corpuscles are not derived from the cells of Schwann at all, but are developed locally in the epithelium (and are therefore ectodermal) and dermis (and are therefore mesodermal) respectively. (Wolff, 1948b.) This is not really surprising when we remember that in such sensory end-organs as a taste-bud the gustatory cells are epithelial.

Much has been made of the fact that there are nerves in the outer part of the choroid just where the choroidal growths usually start; but this is also -where most pigmented cells are normally found. Theobald shows sections which she regards as proof that choroidal growths arise from the ciliary nerves, but all I can say from similar preparations of $m y$ own is that the cells of Schwann were continuous with the tumour cells, a relation produced simply by involvement of the nerve in the tumour, which is of course quite common. We must remember also that tumours of cells of Schwann are usually simple, only very rarely becoming malignant; and, as Willis (1948) points out, they are never pigmented. It would therefore be extremely curious if, with so many nerves in the body, the uveal tract were the only place where tumours arising from the cells of Schwann belonging to nervetrunks, should be not only malignant but pigmented as well.

Finally we come to the origin of the chromatophores. Most observers hold that these pigmented cells are mesodermal in origin. Latterly, however, the suggestion has been put forward that the pigment cells are derived from the neural crest and grow down with the nerves to the skin, etc. This suggestion is largely based on the experimental evidence that a transplanted neural crest will develop pigment. The fact is, however, one cannot be sure that in transplanting so small an area as the neural crest a few adherent mesodermal cells are not transplanted as well.

It is therefore concluded that, in the present state of our knowledge, we should regard the malignant choroidal melanoma as a sarcoma. 


\title{
REFERENCES
}

Collins, Treacher (1926).-Trans. Ophthal. Soc. U.K., 46, 86.

DAWSON (1925).-Edin. Med. J.. 32, 501.

LAWRENCE and JOHNSON (1915).-Choyce's Surgery, 1, 454, London.

MAN N, IdA (1926).-Trans. Ophthal. Soc. U.K., 46, 132.

Masson (1926).-Ann. d'Anat, Path.. 3, 417: 657.

Parsons, J. H. (1904). - Pathology of the Eye, London.

RiBbert, H. (1911).-Lehrbuch alg. Pathologie, 4, 262.

SMith, D. T. (1925).-Bull. Johns Hopkins Hosp., 36, 185.

THEOBALD, G. D. (1937).-A rch. of Ophthal., 18, 971.

UNNA, P. G. (1893).-Berl. Kl. Wochenschr., 30, 14.

WILlis, R. A. (1948).-Pathology of Tumours, 828, London.

WOLFF, EUGENE (1948).-Brit. J. Ophthal., 32, 72.

(1948).-Trans. Ophthal. Soc. U.K., 68 (in the press).

\section{STUDIES ON THE INTRA-OCULAR FLUIDS}

\section{Part 3.- The Penetration of Some Nitrogenous} Substances into the Intra-ocular Fluids.*

BY

Sir Stewart DUKe-Elder, Hugh Davson, and

\author{
A. M. Woodin \\ Ophthalmological Research Unit (M.R.C.) \\ Institute of Ophthalmology, London.
}

EXPERIMENTS on the rate of penetration of sugars (Duke-Elder and Davson, 1949) and salts (Duke-Elder, Davson and Maurice, 1949) from the blood inte the intra-ocular fluids reported earlier in this series have revealed a selectivity in the barrier separating these fluids, inconsistent with the conception of penetration through a simple pore-structure such as would be provided by the intercellular spaces of an endothelial or epithelial membrane. We were forced to conclude, on the basis of these studies, that the penetration of many substances into the intra-ocular fluids represented a transcellular process since it is only in the membranes of cells that we can expect to find a selectivity of the type described (Davson and Danielli, 1942). Experiments on the penetration of some aminocompounds-creatinine, urea, glycine, and alanine-to be described here, support this view. The above-named compounds have the following molecular weights :-

\footnotetext{
Creatinine, 113

Glycine, 75

Urea, 60

Alanine, 89

Dedicated to Professor J. Meller.

* These experiments were carried out by E. J. Ross working in this laboratory : see Brit. J. Ophthal., 33; p. 310. Received for publication, March 12, 1949.
} 